\title{
"It could be Seen more Clearly in Unreasonable Animals than in Humans": The Representation of the Rete Mirabile in Early Modern Anatomy
}

\author{
SEBASTIAN PRANGHOFER*
}

In 2005 Japanese neurosurgeons reported the case of a carotid rete mirabile in a 47-yearold male stroke patient. They documented their observation with MRI scans which represented dark ramifications before a light background and described the structure as a net of collateral vessels, caused by an obstruction of the carotid artery, resulting from a malformation of this vessel. However, they had to concede that the "exact pathogenesis and clinical significance of the rete mirabile remains unknown". ${ }^{1}$ The 2005 case report was significant in three respects. Firstly, it referred to a phenomenon that had allegedly "evaporated from human anatomy after the seventeenth century". ${ }^{2}$ Secondly, pictures were used to support the argument of the authors; and thirdly, the authors showed a great uncertainty about the nature of the phenomenon which they identified as a "carotid rete mirabile".

However, the structure described by the Japanese surgeons shared little but the name with its historical predecessor. While in modern clinical medicine the term rete mirabile describes a pathological symptom, in the early modern period it referred to an anatomical structure. The "wonderful net" 3 was usually described as made from arteries at the base of the skull, but its existence in man, exact appearance and function was heavily contested among anatomists. In tracing the history of this obscure structure, one finds that the uncertainty about the nature of the rete mirabile dates back to the sixteenth century, when its Galenic interpretation as a vital organ, which extracted the animal spirits from the blood, was first doubted by the anatomist and professor of medicine in Bologna, Berengario da Carpi. He claimed that he could not find such a structure during his dissections of human corpses and attributed the production of the animal spirits to the

(C) Sebastian Pranghofer 2009

* Sebastian Pranghofer, MA, Centre for the History of Medicine and Disease, Durham University, Queen's Campus, University Boulevard, Stockton-on-Tees, TS176BH, UK; e-mail: sebastian.pranghofer@durham. ac.uk

I am very grateful to Professor Holger Maehle and Dr Lutz Sauerteig for their encouragement, support and insightful comments when I prepared this paper. I also want to thank the editors and the anonymous reviewers for their critical comments and helpful suggestions. Research for this paper was supported by the Wellcome
Trust, the British Society for the History of Science, the Royal Historical Society and Durham University.

\footnotetext{
${ }^{1}$ Takeshi Mikami, Akira Takahashi, and Kiyohiro Houkin, 'Cartoid rete mirabile associated with subarachnoid hemorrhage', Neurol. Med. Chir., 2005, 45: 201-4.

${ }^{2}$ John M Forrester, 'The marvellous network and the history of enquiry into its function', J. Hist. Med. Allied Sci., 2002, 57: 198-217, p. 209.

${ }^{3}$ Throughout the text the terms "rete mirabile" and "wonderful net" will be used synonymously.
} 


\section{Sebastian Pranghofer}

branches of the internal carotid artery in the pia mater. ${ }^{4}$ A couple of decades after da Carpi had raised his doubts, Andreas Vesalius dismissed the existence of a rete mirabile in human beings in his De humani corporis fabrica (1543). Nevertheless, the rete mirabile in man did not disappear after Vesalius, but remained part of the medico-anatomical discourse.

In the historiography of European anatomy, the rete mirabile has usually been used as an example to illustrate the innovative character of Vesalius's Fabrica-the work which has so often been considered as a turning point in the history of European anatomy. ${ }^{5}$ According to this well established narrative, the example of the rete mirabile shows how Vesalius managed to go beyond the Galenic dogma. ${ }^{6}$ But little work has been done on the post-Vesalian history of the wonderful net. The so far most comprehensive historical account by John M Forrester covered descriptions of the rete mirabile from antiquity to the twentieth century. He described the different ideas of the wonderful net both in human and comparative anatomy, and traced the structure's path into modern zootomy. However, Forrester did little to illustrate the debates among early modern anatomists and their unease with the topic. Also, he neither acknowledged the continuous references to the rete mirabile in human bodies during the eighteenth century, nor did he discuss the usage of the term in twentieth-century clinical medicine. ${ }^{7}$

The fact that the rete mirabile survived the Vesalian challenge in the sixteenth century reflected its standing as a well-established anatomical object. But its survival was only possible through various coexisting assertions about its appearance, nature and function. Both in the Vesalian critique and in subsequent accounts of the structure in the seventeenth and eighteenth centuries, visual representations were used by authors as part of their argument. This historical inconsistency of scientific knowledge raises the question whether and how such images represented reliable visual information. In order to understand the complex functions and meanings of scientific images in early modern anatomy, they have to be seen as part of rhetoric and narrative strategies to negotiate truth and not merely the representations of a particular truth. ${ }^{8}$ Illustrations of the rete mirabile, together with written accounts of it, are analysed in this paper with regard to how they established the wonderful

\footnotetext{
${ }^{4}$ Berengario da Carpi, A short introduction to anatomy (Isagogae brevis), transl. L R Lind, University of Chicago Press, 1959 (1st ed., Latin, 1522), p. 147; Edwin Clarke and C D O'Malley, The human brain and the spinal cord: a historical study illustrated by writings from antiquity to the twentieth century, 2nd ed., San Francisco, Norman Publishing, 1996, pp. 764-7.

${ }^{5}$ For a critical appraisal of this view, see Andrew Cunningham, The anatomical renaissance: the resurrection of the anatomical projects of the ancients, Aldershot, Scolar Press, 1997, pp. 88-142.

${ }^{6}$ For the older literature, see, for example, C D O'Malley, Andreas Vesalius of Brussels, 1514-1564, Berkeley, University of California Press, 1964, pp. 178-9. For a more recent account, see Andrew Wear, 'Medicine in early modern Europe, 1500-1700', in Lawrence I Conrad, Michael Neve, Vivian Nutton, Roy Porter, and Andrew Wear, The
}

western medical tradition: $800 B C$ to $A D 1800$, Cambridge University Press, 1995, pp. 279-80.

${ }^{7}$ Forrester, op. cit., note 2 above.

${ }^{8}$ On the rhetoric of early modern scientific images, see Sachiko Kusukawa, 'The uses of pictures in the formation of learned knowledge: the cases of Leonhard Fuchs and Andreas Vesalius', in Sachiko Kusukawa and Ian MacLean (eds), Transmitting knowledge: words, images, and instruments in early modern Europe, Oxford University Press, 2006, pp. 73-96. The descriptive-empirical nature of seventeenth-century Dutch art is discussed in Svetlana Alpers, The art of describing: Dutch art in the seventeenth century, London, Penguin Books, 1983. New methods of standardizing visual representations in the eighteenth century are the topic of Barbara M Stafford, Body criticism: imaging the unseen in Enlightenment art and medicine, Cambridge, MA, and London, MIT Press, 1991. 


\section{The Representation of the Rete Mirabile in Early Modern Anatomy}

net in human bodies as a matter of fact. In order to understand the persistence of this structure I trace its changing appearances from the Vesalian critique to its virtual disappearance from human anatomy. I draw on both the specialized literature on the anatomy of the brain from the sixteenth to the end of the eighteenth century as well as on general anatomical handbooks. This selection of sources not only allows the study of the dissemination of ideas; the inclusion of the most relevant handbooks makes it possible to assess what might be regarded as widely accepted or "standardized" knowledge.

The first part of this paper introduces the traditional Galenic idea of the rete mirabile as well as its corresponding visual representations, and discusses the sixteenth-century challenges to this concept. In the second part, seventeenth-century debates on the matter, including the Galenists' refusal to accept the new Vesalian anatomy on the one hand and the new physiologies of the rete mirabile on the other hand, are reconstructed. This is followed by a discussion of the developments which led to its disappearance from human anatomy in the eighteenth century. The paper concludes with some suggestions on how to understand the ambiguity, especially of visual representations, of the rete mirabile, and how this reflected strategies to overcome the empirical and conceptual uncertainties surrounding this structure.

\section{The Galenic Understanding of the Rete Mirabile and the Vesalian Challenge}

In Galen's anatomy and physiology the rete mirabile played a crucial role. It was described as a network of fine vessels into which the carotid artery branched out at the base of the cranium. ${ }^{9}$ For Galen the importance of this delicate structure was obvious: "For wherever Nature wishes material to be completely elaborated, she arranges for it to spend a long time in the instruments concocting it." ${ }^{10}$ The function Galen attributed to the rete mirabile was to refine the vital spirit in the blood into the animal spirit, or psychic pneuma, which was seen as a requirement for reasoning, and regarded by Galen also as the driving force behind bodily functions and movement. ${ }^{11}$ This idea of the rete mirabile as a vital organ remained unchallenged in the western medical tradition until the sixteenth century. ${ }^{12}$ Visual representations of this important organ from this early period are scarce, and the depiction of a human head in Antropologium de hominis dignitate (1501) by Magnus Hundt of the University of Leipzig is probably the only model for pre-Vesalian depictions of the rete mirabile. ${ }^{13}$ This rather schematic representation of the human head was still used more than three decades later by Johann Dryander, anatomist at the University of Marburg, for his Anatomiae (1537). ${ }^{14}$ This illustration showed a

\footnotetext{
${ }^{9}$ Galen on the usefulness of the parts of the body: De usu partium, transl. from the Greek by Margaret Tallmadge May, 2 vols, Ithaca, Cornell University Press, 1968, vol. 1, pp. 430-1.

${ }^{10}$ Ibid., p. 432.

${ }^{11}$ Ibid. For a detailed account of Galen's complex concept of pneumatic elaboration and the physiology of the rete mirabile, see Julius Rocca, Galen on the brain: anatomical knowledge and physiological speculation in the second century $A D$, Leiden, Brill, 2003, pp. 208-19.
}

\footnotetext{
${ }^{12}$ Ibid., pp. 249-53.

${ }^{13}$ Forrester, op. cit., note 2 above, p. 204.

${ }^{14}$ Magnus Hundt, Antropologium de hominis dignitate, natura, et proprietatibus, de elementis, partibus et membris humani corporis, Leipzig, Wolfgang Stöckel [printer], 1501, fol. 2v; Johann Dryander, Anatomiae, hoc est, corporis humani dissectionis pars prior, in qua singula quae ad caput spectant recensentur membra, atque singulae partes, singulis suis ad vivum commodissime expressis figuris, deliniantur, Marburg, Eucharius Ceruicorus,
} 


\section{Sebastian Pranghofer}

human head with the different ventricles of the brain and the different senses mapped and indexed (Figure 1). On both Hundt's and Dryander's illustrations the rete mirabile was represented by a hatching pattern above the nose. Neither of these illustrations represented the wonderful net in a naturalistic way resembling some organic form. Also, neither gave an indication of its precise topographical location or physiological relations according to the traditional Galenic account.

A year after Dryander, Vesalius published an illustration of the rete mirabile in relation to the vascular system in his Tabulae anatomicae sex (1538). On the third plate Vesalius depicted the wonderful net at the top in the centre, in the middle of the head as a conjuncture of blood vessels (Figures 2a and 2b). ${ }^{15}$ At least until 1540, Vesalius still firmly believed in the existence of a rete mirabile in man, and saw it in the centre of the "noblest" of the three cavities of the body, the skull. ${ }^{16}$ But only a few years later he dismissed the idea that it existed in man. Comparative dissections of human and animal cadavers had convinced Vesalius that Galen must have been wrong. In 1543, in the Fabrica, Vesalius criticized other physicians for their blind belief in Galen's account of the "wonderful plexus reticularis" (i.e. the rete mirabile). ${ }^{17}$ He tried to falsify the Galenic assumptions about the rete mirabile with his own description of the course of the carotid artery into the head, which was based on his own dissections. ${ }^{18}$ Vesalius still added an illustration to the Fabrica which represented a rete mirabile, but had no resemblance to earlier representations of the organ, except for the hatched structure (Figures 3a and 3b). Usually in the Fabrica the organs would be illustrated both individually and within their topographical context. The rete mirabile, however, was only shown on its own and not in relation to the brain. By isolating the wonderful net from the rest of the body, without showing it in situ on any other illustration in the book, Vesalius used the image as an argument. While he demonstrated that he was very familiar with Galenic anatomy, he also made a point by removing Galen's rete mirabile from human anatomy. ${ }^{19}$

Despite Vesalius's denial of the existence of a rete mirabile in human beings, the structure did not disappear from the anatomical discourse, far from it. Most anatomical handbooks from the second half of the sixteenth until the early eighteenth century discussed it, and many also included illustrations reaffirming the wonderful net. Some authors such as the Spanish anatomist Juan Valverde promoted the Vesalian denial of

1537 , fols $14 \mathrm{r}, 28 \mathrm{r}$, with the index on fol. $27 \mathrm{v}$. The illustration from Hundt's Antropologium is reproduced in Edwin Clarke, Kenneth Dewhurst, An illustrated history of brain function: imaging the brain from antiquity to the present, 2nd ed.,

San Francisco, Norman Publishing, 1996, Figure 32, p. 28.

${ }^{15}$ Andreas Vesalius, Tabulae anatomicae sex: six anatomical tables of Andreas Vesalius, London, privately printed for Sir William Stirling-Maxwell, 1874 (1st ed. 1538).

${ }^{16}$ According to Baldasar Heseler's minutes of Vesalius's anatomical demonstrations at Bologna in 1540 , Vesalius demonstrated the rete mirabile in the head of a sheep during his fifteenth demonstration and in a human head during his twenty-fifth demonstration. Baldasar Heseler, Andreas Vesalius' first public anatomy at Bologna: an eyewitness report by Baldasar Heseler, ed. Ruben Erikson, Uppsala and Stockholm, Almqvist and Wiksells, 1959, pp. 221, 289.

17 “... mirabilis plexus reticularis”. Andreas Vesalius, De humani corporis fabrica libri septem, Basel, Johannes Oporinus, 1543, p. 642. If not indicated otherwise the translations are mine.

${ }^{18}$ Ibid., pp. 642-3.

${ }^{19}$ On Vesalius's use of images as part of an argument, see Kusukawa, op. cit., note 8 above, pp. $87-9$. 


\section{Vniuerfalis figura omnium partium capitis humani cum fua explicatione.}

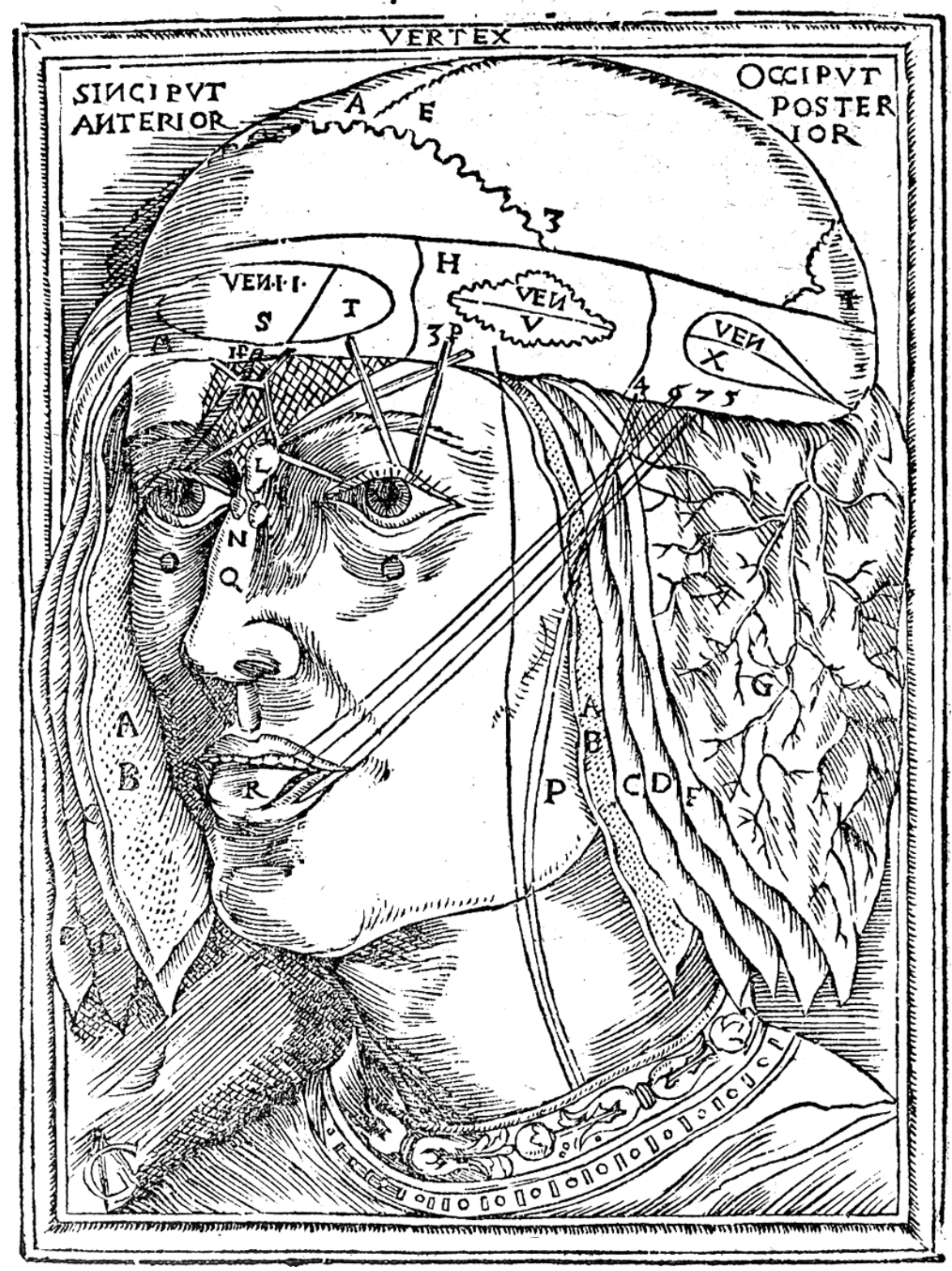

Figure 1: J Dryander, Anatomiae (1537), fol. 28r. The rete mirabile is represented by the hatched structure above the eyes. (Wellcome Library, London.) 


\section{\% ARTERIA MAGNA,AOPTH, הנבוב HAORTI EX SI= \\ NISTRO CORDIS SINV ORIENS, ET VITALEM SPIRITVM TOTI CORPORI DEFERENS, NATV.

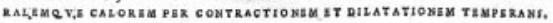

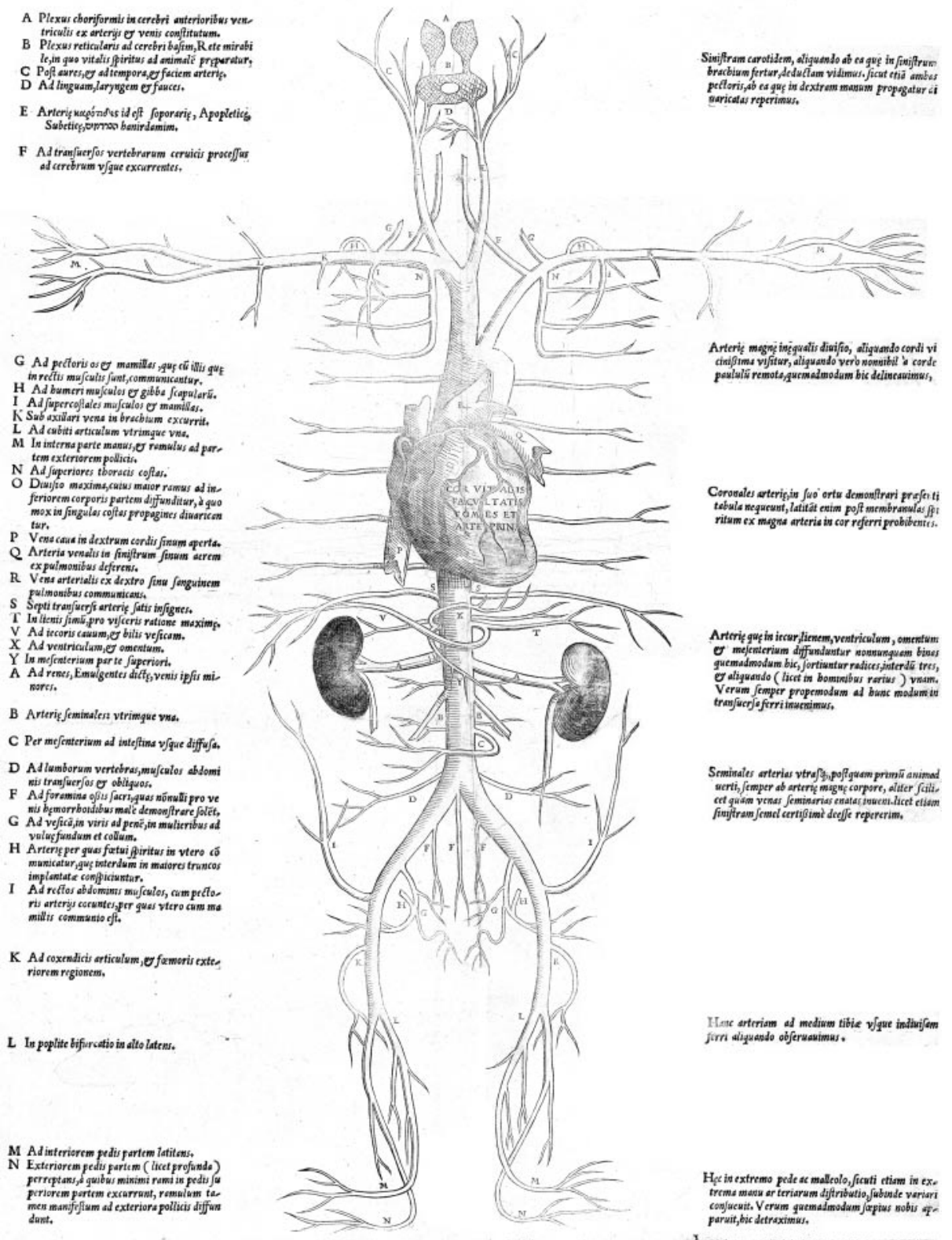

NOTATV DIGNAE ARTERIAE MAGNAE SOBOLES CENTVM ETQVADRAG'NTA SEPTEM APPARENT.

Figure 2a: A Vesalius, Tabulae anatomicae (1538), plate 3. The rete mirabile is represented by the hatched structure in the centre of the head, indexed with the letter B. (Glasgow University Library, Department of Special Collections.) 


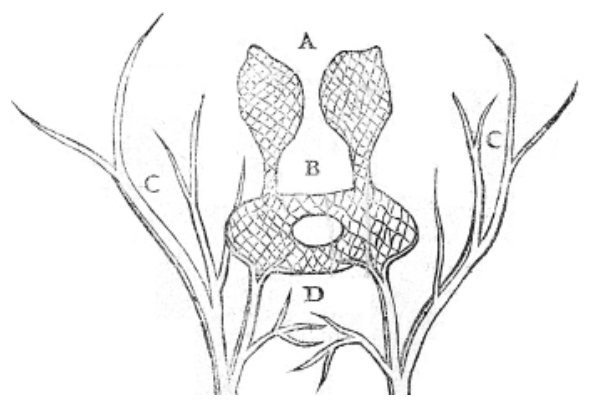

Figure 2b: Detail of Figure 2a showing the rete mirabile enlarged. (Glasgow University Library, Department of Special Collections.)

the status of the structure. He adopted many modified illustrations from Vesalius's Fabrica, but left the illustration of the rete mirabile unchanged. ${ }^{20}$ However, influential and well published anatomists like Andreas Laurentius and Jean Riolan the Younger, who was a fierce critic of Vesalius, did not abandon the Galenic doctrine of the rete mirabile. ${ }^{21}$ Riolan gave a detailed description of its topographic anatomy, citing authors such as Niccolò Massa and Sylvius (Jacques Dubois), and rejected Vesalius's claims that the organ did not exist in human bodies. ${ }^{22}$ Laurentius had no doubts that the rete mirabile existed in humans and even included illustrations representing it, copied after Valverde's plates. $^{23}$

When taking a closer look at illustrated anatomical handbooks it becomes evident that it was not necessarily Vesalius's anatomy which was adopted, but his images which were copied and circulated. While Vesalius's extensive use of illustrations did not find many immediate imitators, ${ }^{24}$ seventeenth-century authors did not ignore the new visual standards set out by De humani corporis fabrica any longer. In the publications by Laurentius, for example, the Vesalian representations of the rete mirabile were used as a model for its illustration. ${ }^{25}$ It appears that the authors of the most successful anatomical handbooks from the late sixteenth century and the first half of the

\footnotetext{
${ }^{20}$ Juan Valverde, Anatome corporis humani, Venice, Juntarius, 1589 (1st ed., Italian, 1559), Tab. II, Lib. V, Fig. XVII, p. 255.

${ }^{21}$ Forrester, op. cit., note 2 above, p. 208. Laurentius, Bauhin and Riolan held chairs for anatomy at the universities of Montpellier, Basel and Paris, respectively. Andreas Laurentius was also probably the most successful author of anatomical handbooks in the first three decades of the seventeenth century. His Historia anatomica humani (1599) saw eleven editions between 1599 and 1628.

${ }^{22}$ Jean Riolan, Anthropographia et osteologia, Paris, D Moreau, 1626, pp. 389-90; Jacques Dubois, In Hippocratis et Galeni physiologiae partem anatomicam isagoge, Basel, Jacob Derbilley, 1556, pp. 246-7; Niccolò Massa, Anatomiae liber introductorius, in quo quamplurimae partes, actiones, atque utilitates humani corporis, nunc primum
}

manifestantur: quae a ceteris tam veteribus, quam recentioribus hucusque praetermissa fuerant, Venice, J Zilletus, 1559, p. 85.

${ }^{23}$ Andreas Laurentius, Historia anatomica humani corporis et singularium eius partis multis controversiis \& observationibus novis illustrata, Frankfurt/Main, I Mettayer [printer], 1600 (1st ed. 1599), p. 391. The rete mirabile is illustrated in figure XVII on p. 209.

${ }^{24}$ Vivian Nutton, 'Representation and memory in renaissance anatomical illustration', in Fabrizio Meroi and Claudio Pogliano (eds), Immagini per conoscere: dal rinascimento alla rivoluzione scientifica, Florence, L S Olschki, 2001, pp. 61-80, on pp. 76-8.

${ }^{25}$ Laurentius, op. cit, note 23 above, p. 209; Caspar Bauhin: Theatrum anatomicum, Frankfurt/Main, Matthaeus Becker, 1605, Lib. III, Tab. XI, Fig. XIV p. 560. 
DE C I M A S X T A SEP TIM I L I B R I

FI G R A.

H A C figura nudam depinximus glandem, qua cerebri pituita excipi tur, uni cum pelui feu infundibulo pituitam buc defcrente, or bic flaccido propendente. A lateribus uero arteriarum foporalium portiones, qua reticularem plexum efformare dicuntur, ita bic expre/simus, uti nobis in ter fecandum occurrere. Atqs, ut eas arteriarum portiones uariè $/ c$ fe cautibus offerunt, ita quoq; uarie cas delineauimus.

A Glans,cerebri pituitam excipiens.

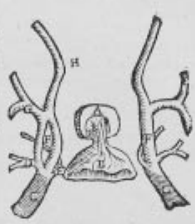

B Peluis, feu infundibulum cerebri pituitam fuper modó dictam glandem deferctis.

C, C Arteriarum portio, qua ecundum fuorü in offe caluaria forminum ductü obliqué ferütur.

$D$ Siniftra arteria ramus in dura membrane finist trum latus cxcurrens.

E Arteria finiftre portio per proprium foramen ad narium ufos amplitudinem pertingens.

$F_{2} F$ Hac fede diuer fam arteric fcriem delineauimus. ac dextrum quidem F arteriam notat caferic ductam ut bic non dirimatur: quemadmodum finiftrum F artcriam banc in duos ramos, qui mox in unum rurfus cocunt, infinuat.

G Arteriarum portiones duram cerebri membranam perreptantes, ac partim in cerebri uentricu los, partim in tenucm membranam cerebribajiobductam digefi.

H Propago arteria per foramen fecundi paris neruorum cercbri caluariam excidens, ac neruum uiforium, ac dein oculum petens.

\section{E C I M A S P T IMA LI B R I SEP TIM I}

FIGVR凹.

H A C figura plexum finximus, cuiuf modi is effe deberet, qui Galeni in $\mathcal{A}, B$. libris de Vfu partiun defcriptionibus conuenirct. Signifisct itag; bic $A$ o B arterias caluariam fubeuntes, moxós, in mirabilem illu plexum diffu

$C_{2} D$. fas. Cucró $\sim \mathrm{D}$ ramos in quos plexus illius propagenes colligütur, qui illis prorfus arteriarum magnitudine re pondent, quas $A \odot B$ indicani-

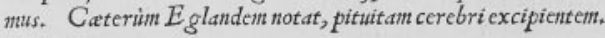

P R AE S ENT I figura arteriarum fub dura cerebri mébrana cöfiftentium, ac ad glandis cerebri pituitam admittentis latus reptan tium ferien depinximus, quam in ouium ac bonum capitibus ob feruamus. Atqj bãc proponere libuit, ne quis nos latêre arbitraretur, que illorum animalium bic cum bomine fit differentia. Significat autem in bacfigura 1 dictam iam fapius glandem, $B \cup C$ arteriarum $\int \mathrm{edem}_{2}$ qua primum in caluariamingrediuntur.

\section{DECIMAOCTAVA SEPTIMI LIBRI FIGVRA.}

$P A R V$ A bac figura erectam finximus peluim, f cu cyatbum, quo cere bripinuta in glandem ipfifubditum diftillat, ac dein bic finximus quatuor ductus äglande pituitä per proxima glandi foramina de ferètes. Indicet igi tur A glandem, cui pituita inflillatur. B peluim, qua bac ducitur. $C, D$, $E$, F ueró, meatus ad ficilior cm pituita buc decübentis egre/fum paratos.

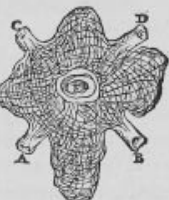

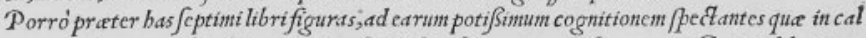
uarie babentur amplitudine, etiam buc faciüt dua figura mox ad fincm primi Capitis libri quar ti additie, o cptem parium neruorum cerebri delineationem exprimêtes: quas qüum illic proli. $x \dot{c}$ indicauerimus, abs rc prorfus e/fet eafdem bic quoq reponerc, et carrü indicế afcriberc. Pra terea figurce oculi conftruftionem exprimentes, ctiam fiad feptimum re ferantur librum, tamen Capiti decimoquarto duntaxat illas praponam, quod oculorum fabrica dedicabitur. At s $_{\text {id }}$ in illis figuris priuatim faciam, quód nulli altcri quàn dicto iam Capiti famulentur.

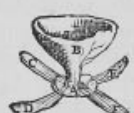

Figure 3a: A Vesalius, De humani corporis fabrica (1543), p. 621. The second figure from the top represents the rete mirabile. (Herzog August Bibliothek Wolfenbüttel. A: 3 Phys. $2^{\circ}$.) 


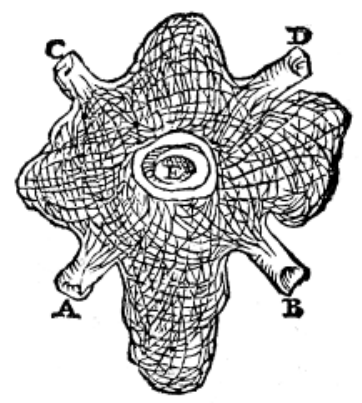

Figure 3b: Detail of Figure 3a showing the enlarged drawing of the rete mirabile, which bears no resemblance to earlier representations. (Herzog August Bibliothek Wolfenbüttel. A: 3 Phys. $2^{\circ}$.)

seventeenth century did not seize on Vesalius's denial of the human rete mirabile and opposed at least parts of Vesalian anatomy. Likewise, the illustrations in the Fabrica did not establish a universal iconographic standard for the visual representation of anatomy. ${ }^{26}$ More than the illustrations themselves, Vesalius's ambition to overcome the older, not very detailed and often schematic representations became a new focal point of anatomical drawings. ${ }^{27}$

Vesalius's illustrations were not the only iconographic model for anatomical representations. Some of the frequently copied anatomical illustrations in the seventeenth century, which also followed a naturalistic approach, were done after the plates in Adriaan van der Spiegel's De humani corporis fabrica (1627). They were originally the work of his predecessor in the chair of anatomy at the University of Padua, Julius Casserius, and added by Spiegel's editor. ${ }^{28}$ Among those included in Spiegel's anatomical handbook was a new depiction of the rete mirabile, which significantly differed from the Vesalian iconography (Figures 4a and 4b). ${ }^{29}$ In Spiegel's image the wonderful net was not represented isolated, but in relation to the brain, its nerves and blood vessels. The illustration represented the brain from below after it had been separated from the spinal cord and cleaned from surrounding tissue. The rete mirabile (indexed with the letter "L") branched out from the carotid artery (indexed with the letter "K"). The branches

\footnotetext{
${ }^{26}$ On Vesalius's visual paradigm in general, see Kusukawa, op. cit., note 8 above. On the different and controversially debated modes and concepts for an appropriate visual representation of the anatomical body, especially in the eighteenth century, see James Elkins, 'Two conceptions of the human form: Bernhard Siegfried Albinus and Andreas Vesalius', Artibus et Historiae, 1986, 7 (14): 91-106; Stafford, op. cit., note 8 above, pp. 108-18; Katja Regenspurger and Patrick Heinstein, 'Justus Christian Loders Tabulae anatomicae (1794-1803). Anatomische Illustrationen zwischen wissenschaftlichem, künstlerischem und merkantilem Anspruch', Medizinhist. J., 2004, 38: 245-84, pp. 256-9.
}

\footnotetext{
${ }^{27}$ Vesalius's design of his anatomical illustrations also intended to provide naturalistic representations of the human body. They were thought to help those who were not able to attend dissections on a regular basis themselves. Vesalius, op. cit., note 17 above, fols $3 \mathrm{v}-4 \mathrm{r}$.

${ }^{28}$ Ludwig Choulant, History and bibliography of anatomic illustration in its relation to anatomic science and the graphic arts, trans. and ed. Mortimer Frank, University of Chicago Press, [1920], p. 255.

${ }^{29}$ Adriaan van der Spiegel, 'De humani corporis fabrica', Adriaan van der Spiegel, Opera omnia quae extant, Tomus I, Amsterdam, Johannes Blaeu, 1645 (1st ed. 1627), Lib. X, Tab. X, p. 195.
} 


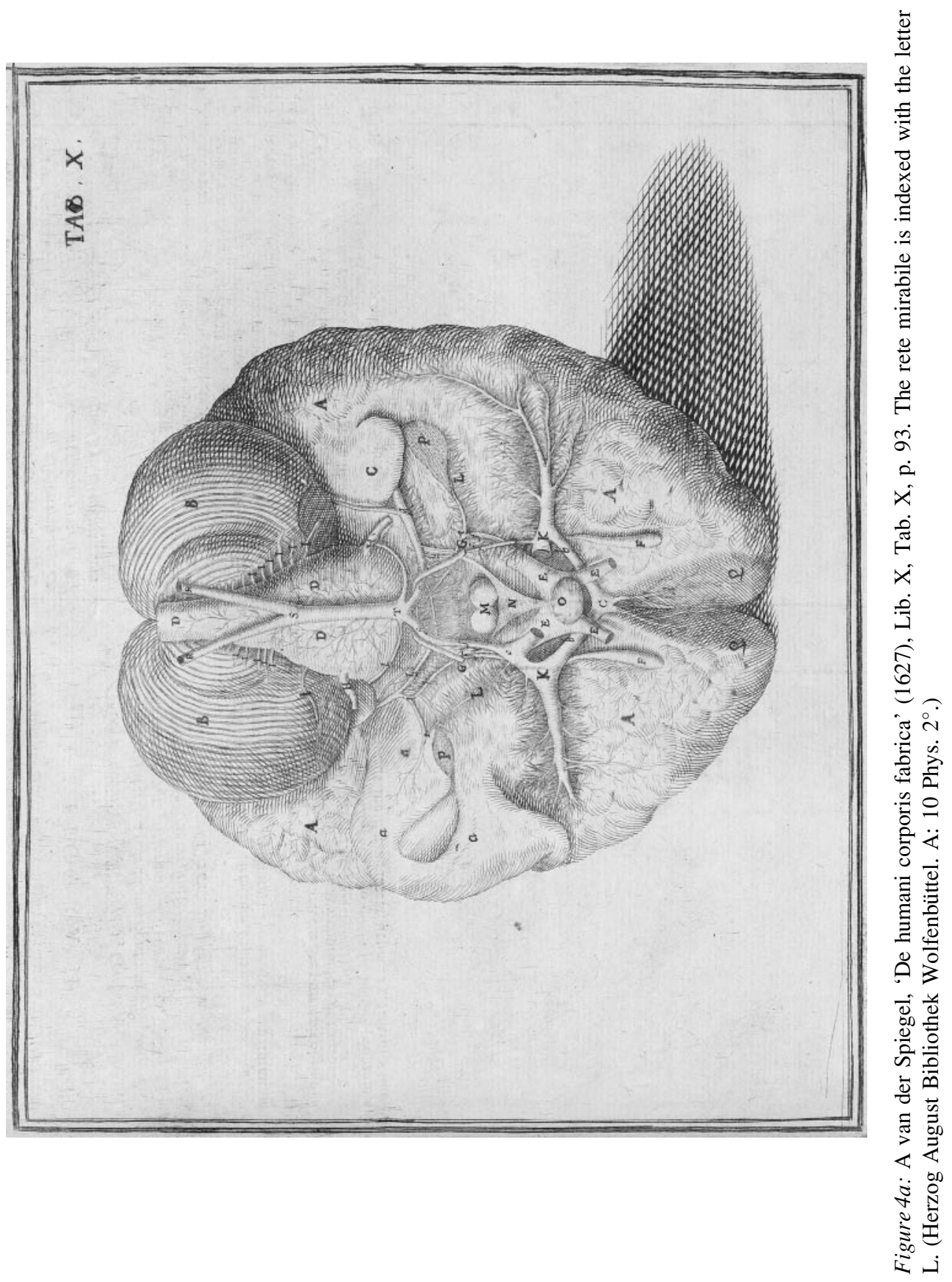




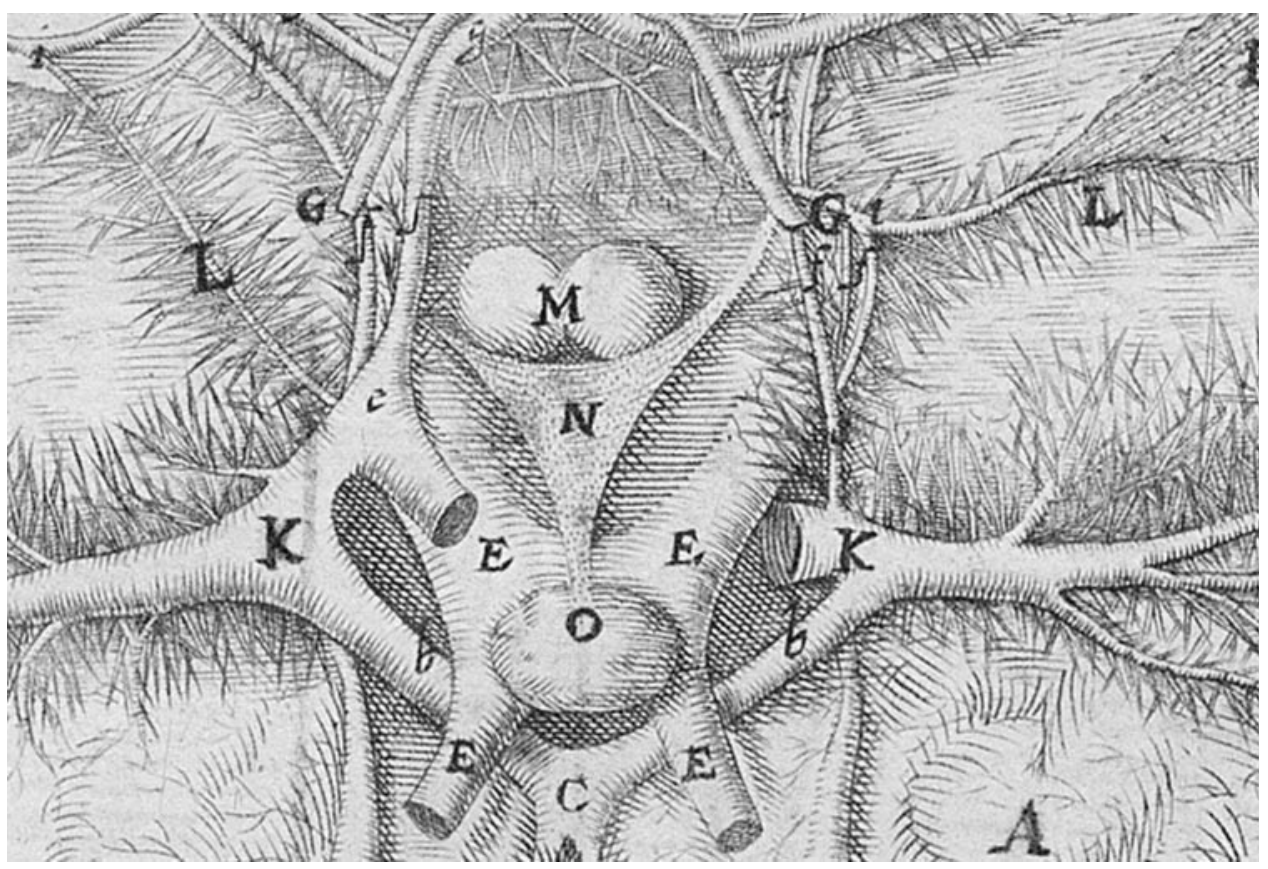

Figure 4b: The difference between Spiegel's depiction of the rete mirable (indexed with the letter L) and Vesalius's is evident in this detail of Figure 4a. (Herzog August Bibliothek Wolfenbüttel. A: 10 Phys. $2^{\circ}$.)

representing the rete mirabile were depicted in a naturalistic way and resembled the blood vessels surrounding the brain. There was also no similarity to the hatched structure of the rete mirabile in Vesalian and older illustrations. While Spiegel had no doubt that the rete mirabile existed in humans, he admitted that it was difficult to find and more clearly visible in sheep. ${ }^{30}$

Difficulties in identifying the exact position and appearance of the wonderful net were also reflected in the illustrations to the work of Johan Vesling. Vesling was one of Spiegel's successors to the chair of anatomy at the University of Padua, and his Syntagma anatomicum (1641) was the most successful anatomical handbook of the second half of the seventeenth century with sixteen editions in Latin, German, Dutch and English. On page 195, figure III represented the brain from below, as in the illustration in Spiegel's De humani corporis fabrica (Figure 5). However, in contrast to that in Spiegel's work, the rete mirabile (indexed with the letter "P") did not branch off the carotid artery and merge into the plexus choroides, but was simply represented by branches which came off the carotid artery (indexed with the letter "C") and then spread over the surface of the brain. ${ }^{31}$

\footnotetext{
${ }^{30}$ Adriaan van der Spiegel, De humani corporis fabrica libri decem, tabulis XCIIX aeri incisis ... nec ante hac visis exornati ... opus posthumum, Venice, Deuchinus, 1627, p. 317.
}

\author{
${ }^{31}$ Johann Vesling, Syntagma Anatomicum. Locis \\ plurimis actum, emendatum, novisque iconibus \\ diligenter exornatum, Padua, P Frambotti, 1647 \\ (1st ed. 1641), Tab. III, Cap. XIV, Fig. III.
}




\section{Sebastian Pranghofer}

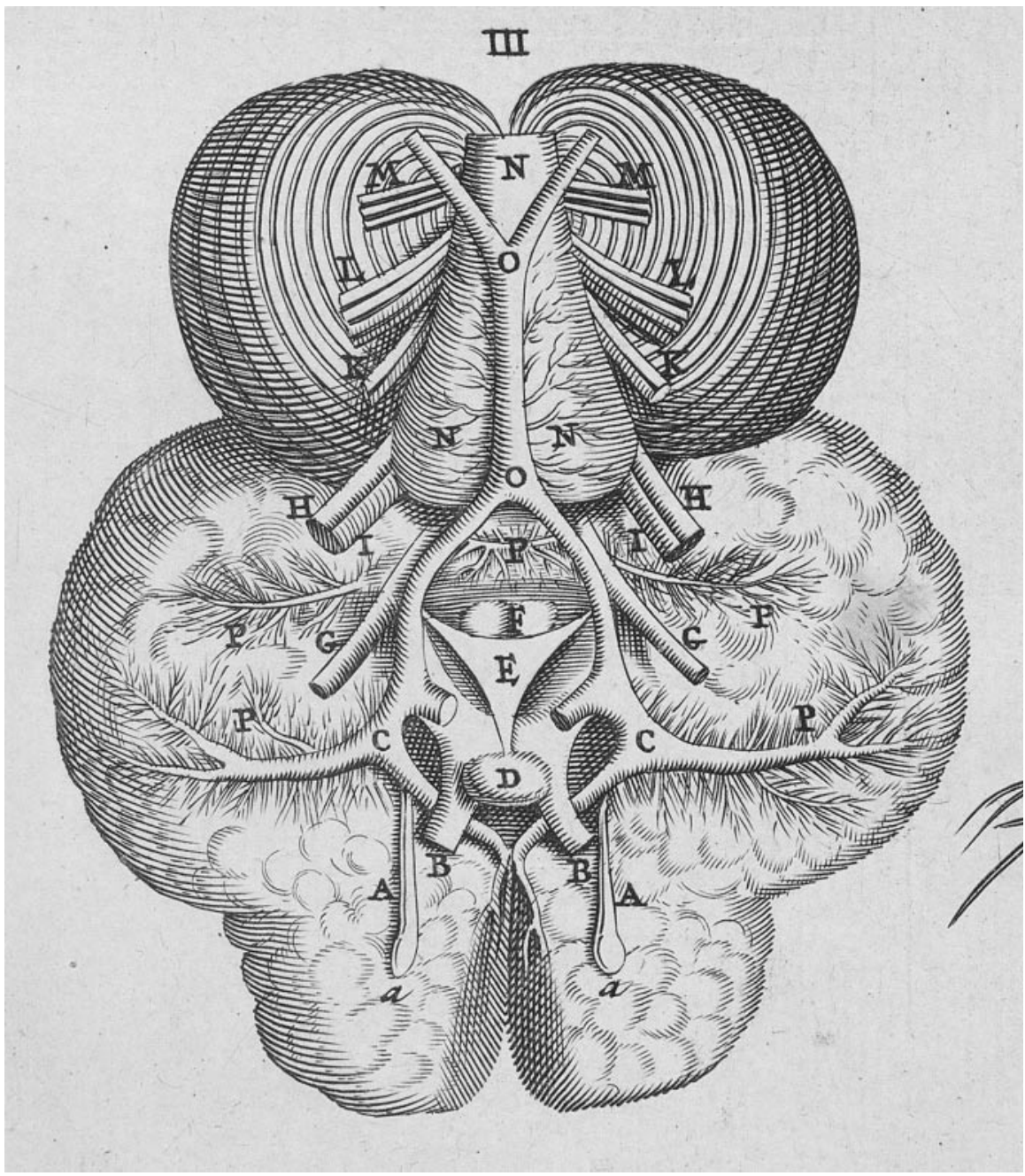

Figure 5: J Vesling, Syntagma anatomicum (1647), Tab. III, Cap. XIV, Fig. III. The rete mirabile is indexed with the letter $\mathrm{P}$ in the middle left of the image. (Herzog August Bibliothek Wolfenbüttel. A: 1.2 Quod. (2).)

Vesling's written account of the appearance and the function of the rete mirabile was remarkable in two respects. Firstly, he upheld the idea of its existence in man, although he admitted, that "it could be seen more clearly in unreasonable animals than in humans". ${ }^{32}$ Secondly, Vesling followed the traditional Galenic account of the physiology of the rete

32 “... wiewohl solches [the rete mirabile] in etlichen unvernünftigen Thieren klärer alß in dem Menschen zu sehen." Johann Vesling, Künstliche Zerlegung Menschlichen
Leibes, Lateinisch geschrieben, und mit vielen schönen Figuren gezieret ...,

Leiden, Wyngaerden, 1652 (1st ed. Latin 1641), p. 132. 


\section{The Representation of the Rete Mirabile in Early Modern Anatomy}

mirabile by ascribing to it the same function of extracting the animal spirits from the blood. However, a few pages earlier this function had been ascribed to the plexus choroides as well. ${ }^{33}$ Thereby Vesling identified an organ that could fulfil the physiological function of the rete mirabile, in case the latter could not be found. By abandoning the rete mirabile as the sole producer of the animal spirits, he paved the way for new physiological explanations of this structure, but he also made the rejection of its existence in humans possible. Vesling's other important idea was that the different appearance of the rete mirabile in the cadavers of humans and of animals could indicate a difference in mental capacities and allow a distinction between man and "unreasonable animals". ${ }^{34}$ Both ideas became important themes in the anatomical discussion of the rete mirabile in the seventeenth and eighteenth centuries. These debates were initiated by the new research interest in the anatomy and physiology of the brain from the 1650s which was based on iatromechanistic concepts but also relied on empirical observation.

\section{New Physiologies of the Rete Mirabile in the Seventeenth Century}

During the second half of the seventeenth century the structure and function of the brain attracted increasing interest from anatomists and resulted in the publication of three groundbreaking works on the anatomy of the brain within just eleven years, between 1658 and 1669: Johann Jakob Wepfer's Observationes anatomicae (1658), Thomas Willis's Cerebri anatome (1664), and L'anatomie du cerveau (1669) by Nicolaus Steno. While Wepfer's study was particularly concerned with apoplexy, Willis provided the first comparative handbook on the anatomy and physiology of the brain. Compared with these two comprehensive works, Steno's little treatise appeared to be the least significant, but was an important methodological account and a "programme for brain research", ${ }^{35}$ as well as a pointed critique of both the traditional anatomical teaching in Paris and Cartesian theories of the brain. ${ }^{36}$ This short work clearly set out a new epistemological foundation for empirical, iatromechanistic brain research. Steno advocated an "anatomical method" which was based on the assumption that a more detailed knowledge of the structure of the brain would lead to better understanding of its function. ${ }^{37}$ By this method a most accurate dissection of the brain would follow the nerves through the substance of the brain to their origins. ${ }^{38}$ Although Steno did not mention the wonderful net in his treatise, his method was designed to solve the major problem caused by doubts of the existence of a rete mirabile in man: the question where the animal spirits were produced. Since these spirits were distributed by the nerves, following the nerves to their origin would have led the anatomist to the source of the animal spirits.

\footnotetext{
${ }^{33}$ Ibid., p. 128.

${ }^{34}$ Ibid., p. 132.

${ }^{35}$ Nicolaus Steno, Lecture on the anatomy of the brain, ed. Gustav Scherz, Copenhagen, A Busck, 1965 (1st ed., French, 1669), p. VII.

${ }^{36} \mathrm{G}$ Stern, 'Introduction: Niels Stensen's Discourse', ibid., pp. 61-103, on pp. 74-7.

${ }^{37}$ William Bynum argued that the "anatomical method" was the predominant method of anatomical/physiological research until the early
}

nineteenth century and was also used by Thomas Willis. William F Bynum, 'The anatomical method, natural theology, and the function of the brain', Isis, 1972, 64: 444-68, p. 446.

${ }^{38}$ Steno, op. cit., note 35 above, pp. 7-9. On Steno's method, see also Adolf Faller, 'Die Präparation der weißen Substanz des Gehirns bei Stensen, Willis und Vieussens', Gesnerus, 1982, 39: 171-93, pp. 176-80. 


\section{Sebastian Pranghofer}

Following such a deductive approach Johann Jakob Wepfer, town physician in Schaffhausen in Switzerland, had carried out his study on apoplexy a few years earlier. ${ }^{39}$ His book started with four case histories of patients who had suffered from a fatal cerebral haemorrhage. ${ }^{40}$ These were followed by an account of apoplexy which included a review of the medical literature on the topic in the style of traditional humanist commentaries. ${ }^{41}$ Subsequently a more detailed pathological discussion of the cases followed. The starting point for Wepfer's discussion of apoplexy was the idea that it was caused by an obstruction of the cerebral vessels and ventricles. ${ }^{42}$ In order to identify the causes and consequences of such obstructions, he gave a fairly detailed account of the anatomy and physiology of the brain, especially of the production and distribution of the animal spirits. Wepfer also touched upon the issue of the rete mirabile, referring to the Galenic definition of the wonderful net: "Where the branches, i.e. of the carotid [artery], come together and intertwine, they form a rete mirabile arteriosum. ${ }^{43} \mathrm{He}$ described this definition as highly contested among anatomists, and discussed a number of authors who either insisted on or doubted the existence of a rete mirabile in man. ${ }^{44}$

Over the next fourteen pages Wepfer carefully evaluated different accounts of the appearance and physiology of the rete mirabile, before he came to the conclusion that there was no such structure in human beings. However, this meant that the rete mirabile could not receive and refine the vital spirits either. ${ }^{45}$ It also left Wepfer with two further problems: why was there a rete mirabile in animals, and where were the animal spirits produced if not in this organ? He solved the first problem by speculating that since the carotid artery, which rose directly to the dura mater and the brain, was shorter in animals than in man, it was necessary to slow down the influx of the blood, which he thought was the function of the rete mirabile in animals. ${ }^{46}$ Wepfer not only dismissed the idea that the vital spirits were refined into animal spirits in the rete mirabile, but also denied that the animal spirits were produced in the ventricles of the brain. Instead he suggested that the animal spirits were produced in the white substance of the brain, which solved his second problem of identifying the location where the vital spirits were transformed. ${ }^{47}$

\footnotetext{
${ }^{39}$ Wepfer's research was methodologically rigid and based on accurate observation.

He adopted a similar approach in his work on toxicology. Andreas-Holger Maehle, Johann Jakob Wepfer (1620-1695) als Toxikologe, Aarau, Sauerländer, 1987, p. 127.

${ }^{40}$ Regarding the innovative character of Wepfer's work, see Clarke and O'Malley, op. cit., note 4 above, pp. 769-75. Clarke and O'Malley credited Wepfer with providing the final proof that the rete mirabile was absent in man (p. 769) and also underlined his contributions to the anatomy of the brain by giving the hitherto most accurate account of the cerebral vascular system (p. 771). On Wepfer's anatomy in general, see Henry Nigst, Das anatomische Werk Johann Jakob Wepfers (1620-1695), Aarau, H R Sauerländer, 1947.

${ }^{41}$ On the use of commentaries in early modern anatomy, see Roger K French, 'Berengario da Carpi and the use of commentary in anatomical teaching', in Andrew Wear, Roger K French and Iain M Lonie
}

(eds), The medical renaissance of the sixteenth century, Cambridge University Press, 1985, pp. 42-74, and, more recently, Rafael Mandressi, 'Métamorphoses du commentaire: projets éditoriaux et formation du savoir anatomique au $\mathrm{XVI}^{\mathrm{e}}$ siècle', Gesnerus, 2005, 62: 165-85.

${ }^{42}$ Johann Jakob Wepfer, Observationes anatomicae, ex cadaveribus eorum, quos sustulit apoplexia: cum exercitatione de eius loco affecto, Schaffhausen, Alexander Rieding, 1675 (1st ed. 1658), pp. 20-1.

43 "Ubi rami, scilicet carotidis, coentus \& intertexti, Rete mirabile arteriosum constituent." Ibid., p. 26.

${ }^{44}$ Ibid., pp. 26-9.

${ }^{45}$ Ibid., p. 52.

${ }^{46}$ Ibid., pp. $50-2$.

${ }^{47}$ A Karenberg, 'Johann Jakob Wepfers Buch über die Apoplexie (1658). Kritische Anmerkungen zu einem Klassiker der Neurologie', Nervenarzt, 1998, 69: 93-8, p. 95. 


\section{The Representation of the Rete Mirabile in Early Modern Anatomy}

Thomas Willis, professor of natural history at the University of Oxford, took up Wepfer's ideas about the rete mirabile in his Cerebri anatome (1664). His account was very similar to Wepfer's. ${ }^{48}$ Willis assumed that in man and horses the carotid artery entered the brain in a single meandering trunk, whereas in other animals it branched out in a rete mirabile under the dura mater to ease the pressure of the blood on the brain. ${ }^{49}$

If the reason of this kind of Conformation be inquired into, it easily occurs, that in an human Head, where the generous Affections, and the great forces and ardors of the Soul are stirred up, the approach of the blood to the confines of the Brain, ought to be free and expeditious; and it is behoveful for its River not to run into narrow and manifoldly divided Rivulets, which would scarce drive a Mill, but always with a broad and open chanel, such as might bear a Ship under Sail. ${ }^{50}$

This argument gave reasons for the absence of a rete mirabile in human beings and credited them with a superior status over animals. Willis underlined the imperfect nature of the rete mirabile by the other three functions he ascribed to it. According to him its first function was to regulate the pressure of the blood flow into the brain. The second was to drain superfluous fluids from the watery blood in animals. Finally the wonderful net also offered a backup capacity in case of an obstruction of the arteries, since its complex branches opened different ways for the blood into the brain. ${ }^{51}$ Generally, unlike Wepfer, Willis did not frankly dismiss observations of the wonderful net in man, but argued that "it is only in those sort of man ... being of a slender wit or unmoved disposition". 52 Thereby he once again emphasized the imperfect nature of the rete mirabile.

However, Willis had to admit that horses also lacked a rete mirabile, which he explained with the "noble" nature of this animal. Yet to maintain human superiority, he argued that the brains of horses were still of a weaker constitution than human brains, and, to ease the blood pressure, the carotid artery was split in two interconnected branches in horses. ${ }^{53}$ To illustrate his point Willis added drawings of the rete mirabile to his account, which represented the carotid artery in man (Figure 6, Fig. I), the carotid arteries in a horse (Figure 6, Fig. II), and the rete mirabile in a calf (Figure 6, Fig. III). Although the caption claimed that the illustration showed the situation of the carotid arteries in man and horses within the skull, they both appeared totally isolated and no hint was given to the relation of these structures to the rest of the body. The representation of the rete mirabile was even more abstract. In the centre, an archway-like shape indexed with the letter $\mathrm{C}$ represented the pituitary gland. Alongside the gland were white branches which were indexed on the right with the letter B and represented the "Net-like Infoldings of the Vessels stretched out by that Chanel towards the pituitary Kernel". 54 The said channel was represented by a light vertical line at the right indexed with the letter A and identified as the artery. ${ }^{55}$ While the representations of the arteries in humans and horses were still naturalistic enough to make them appear as vessels, and they were

\footnotetext{
${ }^{48}$ Thomas Willis, The anatomy of the brain and nerves, facsimile of the 1681 English edition, ed. William Feindel, Birmingham, AL, Classics of

Medicine Library, 1978 (1st ed., Latin, 1664), p. 57.

${ }^{49}$ Ibid., p. 84.

${ }^{50}$ Ibid.
}

${ }^{51}$ Ibid., p. 85.
${ }^{52}$ Ibid.
${ }^{53}$ Ibid.
${ }^{54}$ Ibid., p. 86.
${ }^{55}$ Ibid. 


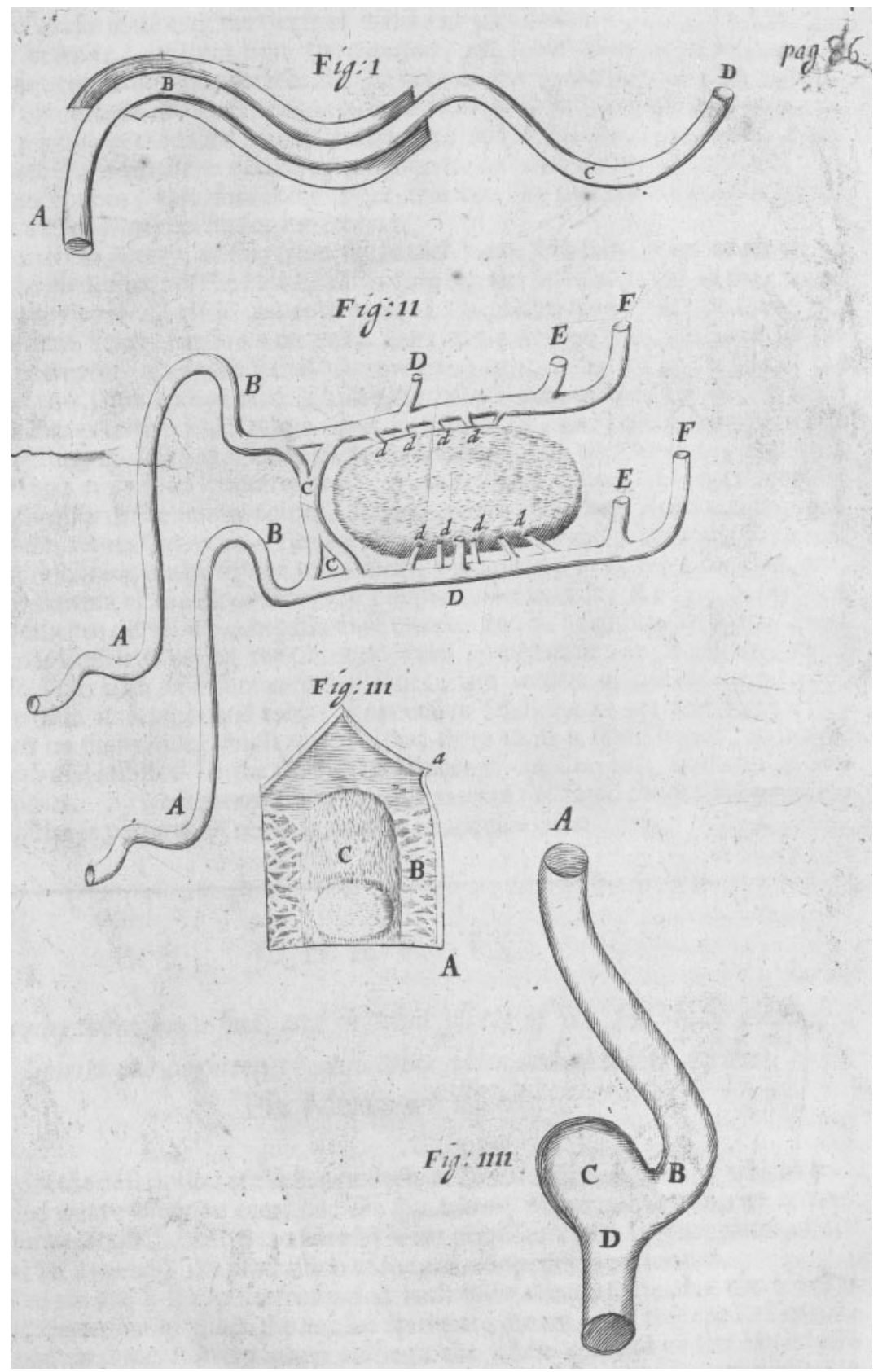

Figure 6a: $\mathrm{T}$ Willis, The remaining medical works of that famous and renowned physician Dr Thomas Willis ... VI. The anatomy of the brain (1681), plate after p. 86. Fig. III represents the rete mirabile in a calf. (Wellcome Library, London.) 


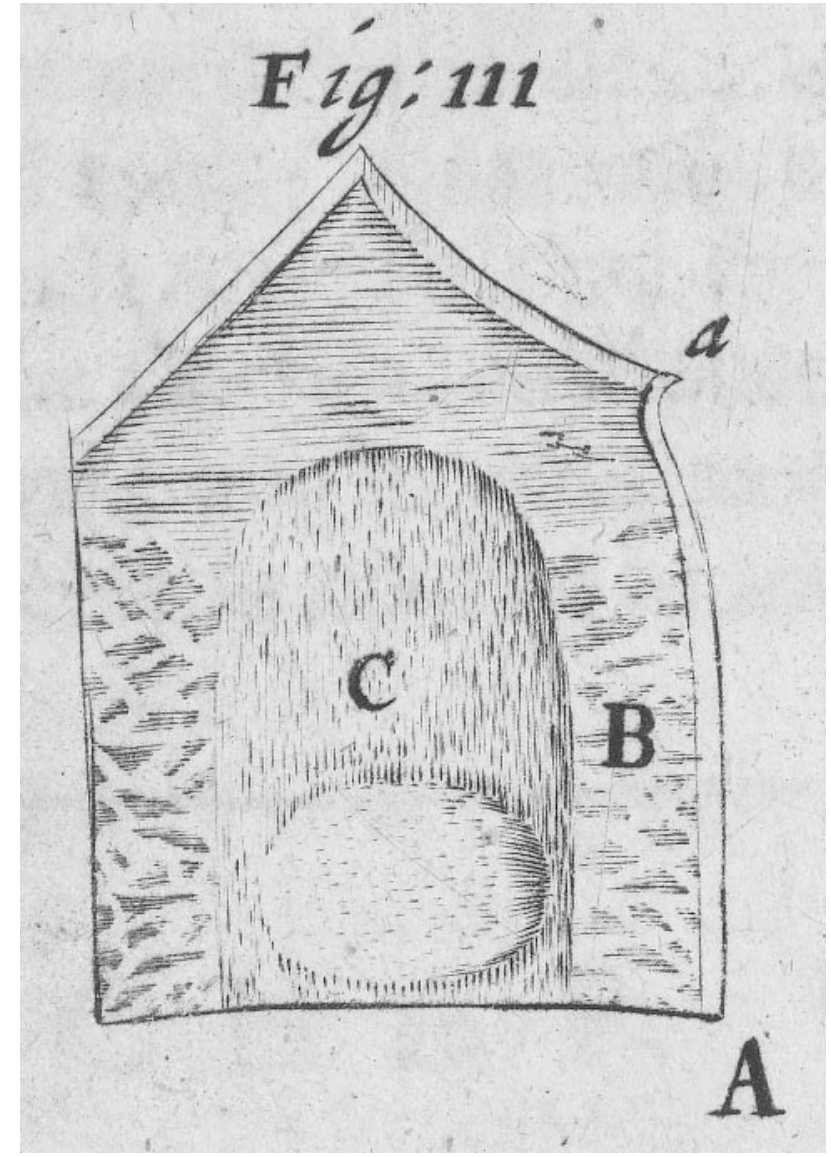

Figure 6b: Enlarged version of Willis's of Fig. III, representing the rete mirabile in a calf. (Wellcome Library, London.)

also accurately indexed, the representation of the rete mirabile was quite abstract and not accurately indexed, which left it without any resemblance to an organic form.

The mechanistic concept of the rete mirabile phrased by Wepfer and Willis quickly made its way into both specialized publications on the anatomy of the brain and anatomical handbooks. But instead of simply adopting the new theories, most authors only picked up certain ideas and combined them with older views. Many refused to dismiss the possibility that the rete mirabile existed in man, such as the French anatomist and Cartesian Raymond de Vieussens, who rejected Willis's assertion that the structure consisted of arteries, veins and nerves and could be found only in animals and just on very rare occasions in humans. Based on experiments using injections of blood-coloured fluid, he claimed that the wonderful net was composed of veins and arteries only and a feature of human anatomy, even though it was very small. Despite his criticism of Willis, Vieussens accepted that the rete mirabile regulated the blood flow to the brain, but still 


\section{Sebastian Pranghofer}

maintained that it refined the animal spirits before they were referred to the pituitary gland. ${ }^{56}$ The English physician Henry Ridley was also happy to accept that the rete mirabile merely regulated the blood flow to the brain, and was thus bigger in animals with a prone position than in man. ${ }^{57}$ Nevertheless, he insisted that he had "never found the Rete wanting, or with any difficulty discoverable in Men, springing from and lying on the inside of each Carotid Artery". 58

A certain reluctance completely to give up the rete mirabile in man was also reflected in the most successful anatomical handbooks of the late seventeenth and early eighteenth centuries. The Dutch physician and anatomist Ysbrand van Diemerbroeck claimed in his Anatome corporis humani (1672)-eleven editions had appeared by 1695-that he had found the wonderful net in corpses which he had dissected by his own hand. ${ }^{59}$ As to the physiological function of the rete mirabile Diemerbroeck agreed with Willis and regarded it as a structure which regulated the speed of the blood flowing into the brain. ${ }^{60}$ The Flemish anatomist Philip Verheyen also described the rete mirabile in his anatomical handbook, which had thirteen editions published by $1739 .{ }^{61}$ Stephen Blankaart, a Dutch physician, was one of the few authors who unconditionally followed Willis. In his Nieuw-hervormde anatomie (1678) he described the rete mirabile at the base of the skull, where the carotid artery entered the head, next to the glandula pituitaria. Blankaart claimed that the rete mirabile could be found in certain animals only-not in man and horses-and regarded the regulation of blood flow as its function. ${ }^{62}$

Empirical observation of the structure, form and functions of the body was the dominant anatomical method of the seventeenth century. This method required diligent manual dissection and close inspection as well as carefully executed experiments, usually involving injections. ${ }^{63}$ Only based on the results of such investigations, the actions of

\footnotetext{
${ }^{56}$ Raymond de Vieussens, Neurographia universalis: Hoc est, omnium corporis humani nervorum, simul \& cerebri, medullaque spinalis descriptio anatomica, Leiden, Johannes Certe, 1685 (1st ed. 1684), pp. 46, 48.

On Vieussens' Cartesian background and experimental research in general, see

C E Kellett, 'The life and work of Raymond

Vieussens', Annals of Medical History, 3rd series, 1942, 4: 31-54.

${ }^{57}$ Henry Ridley, The anatomy of the brain: containing its mechanism and physiology; together with some new discoveries ... of ancient and modern authors upon that subject, London, Samuel Smith and Benjamin Walford, 1695, p. 64.

${ }^{58}$ Ibid., pp. 64-5.

59 "In homine vero exiliis \& obscurior est." (“In humans, however, it is thin and obscure."), Ysbrand van Diemerbroeck, Anatome corporis humani, plurimis novis inventis instructa variisque observationibus, et paradoxis, cùm medicis, tùm physiologicis adornata, Geneva, Samuel de Tournes, 1679 (1st ed. 1672), p. 529.

${ }^{60}$ Ibid., pp. 529-30.

${ }^{61}$ Philippus Verheyen, Anatomie, oder Zerlegung des menschlichen Leibes ... , Königsberg and Leipzig,
}

Christoph Gottfried Eckart, 1739 (1st ed., Latin, 1693), pp. 502-3.

${ }^{62}$ Stephan Blankaart, Reformierte Anatomie oder Zerlegung des menschlichen Leibes, Leipzig, Moritz Georg Weidmann, 1691 (1st ed., Dutch, 1678), pp. 212-14.

${ }^{63}$ Blankaart, for example, described an experiment to demonstrate the structure of the rete mirabile in relation to the plexus retiformis by injecting wax or ink. Ibid., pp. 216-17. A general account of the history of the use of injections in anatomical research can be found in F J Cole, 'The history of anatomical injections', Stud. Hist. Method Sci., 1921, 2: 1285-343; Adolf Faller, Die

Entwicklung der makroskopisch-anatomischen Präparierkunst von Galen bis zur Neuzeit, Basel, S Karger, 1948. Faller observed that well into the seventeenth century the knife remained the prime tool for anatomical research (ibid., p. 54). However, the increasing use of injections for research into the vascular system during the second half of the seventeenth century resulted in new observations. This partly explains the ongoing controversies about the rete mirabile, since such observations demanded explanation: vascular ramifications at the base of the brain as a result of injections could either be 


\section{The Representation of the Rete Mirabile in Early Modern Anatomy}

the body and further reasoning would lead to a comprehensive understanding and knowledge of the body which integrated its structure, form and function. ${ }^{64}$ This holistic approach caused serious problems when the often inconclusive findings from dissections and injections were confronted with the ancient tradition. In the case of the rete mirabile this led to doubts about the actual appearance, function and nature of this structure, and authors like Wepfer and Willis denied or at least heavily doubted its existence. This made new explanations for the physiology of the rete mirabile necessary, since it was still found in animals. The most widely accepted theory, which was also quickly picked up by authors of anatomical handbooks like Blankaart and Diemerbroeck, was that the wonderful net regulated the speed of the blood flowing into the brain. As a result of this iatromechanist interpretation of the purpose of the wonderful net, the rete mirabile lost its important function of generating the animal spirits, which were now, for example according to Willis, produced in the cortex. ${ }^{65}$ The result was a devaluation of the structure not only by those who denied its existence in man, but also by those who maintained that it could at least occasionally be found in human beings.

These uncertainties were reflected by new visual representations of the rete mirabile, which appeared and were frequently copied during the seventeenth century (Figures 4, 5 and 6). They did not clarify the appearance, structure and location of the wonderful net. These illustrations failed to establish a consistent iconography and therefore could not represent the rete mirabile as a well established anatomical fact. They created tensions between the textual tradition, which was apparent in Wepfer's long literature review in his book on apoplexy, and the desire for empirical evidence supported by descriptive visual representations of human anatomy. This conflict was not limited to seventeenthcentury anatomy, but deeply rooted in early modern (visual) culture. Within an "emblematic world view" every object represented various complex metaphorical and symbolical meanings. ${ }^{66}$ In images, iconographic references could associate the represented object with narratives from the bible or ancient mythology. This approach was rivalled by an understanding of the material world which was based on detailed observation, minute description and exact visual representation. ${ }^{67}$ However, the lack of both meaningful explanations and reliable descriptions of the rete mirabile made it difficult to establish a standard for a truthful visual representation of this elusive object.

identified as a rete mirabile or, because of their very different appearance from traditional accounts of the rete mirabile, be regarded as a proof that the wonderful net did not exist in certain species.

${ }^{64}$ Andrew Cunningham, 'The pen and the sword: recovering the disciplinary identity of physiology and anatomy before 1800: II, old anatomy - the sword', Stud. Hist. Phil. Biol. Biomed. Sci., 2003, 34C:

51-76, pp. 55-6.

${ }^{65}$ Willis, op. cit., note 48 , pp. $92-3$.

${ }^{66}$ The term "emblematic world view" was coined by William B Ashworth, who regarded the emblem as the key to Renaissance understanding of the world. The full meaning of an emblem could only be fully comprehended when all three parts, the image as well as the motto and the epigram, were considered.
Accordingly, a true understanding of an object from the natural world could only be acquired through a comprehensive knowledge of its meanings. William Ashworth, 'Natural history and the emblematic world view', in David C Lindberg and Robert S Westman (eds), Reappraisals of the scientific revolution, Cambridge University Press, 1990, pp. 303-32.

${ }^{67}$ Alpers, op. cit., note 8 above, pp. xxiv-xxv. Hal Cook recently showed how such a new form of objectivity, which was characterized by detailed and exact description of the material world, emerged and situated it within the socio-cultural and economic context of the Dutch Golden Age. See Harold J Cook, Matters of exchange: commerce, medicine, and science in the Dutch Golden Age, New Haven and London, Yale University Press, 2007. 


\section{Sebastian Pranghofer}

\section{The Disappearance of the Rete Mirabile from Human Anatomy}

Despite its ambiguity, the rete mirabile continued to feature in anatomical textbooks of the eighteenth century such as The anatomy of the humane body (1698) by the English physician James Keill, which had sixteen editions by 1771 . Keill supported the idea that the wonderful net regulated the speed of the blood flowing into the brain, but he did not specify whether he was referring to human or animal brains. ${ }^{68}$ A more sophisticated account of the structure could be found in the comparative anatomical handbook Anthropologia nova (1707) by the English physician James Drake. For Drake the function of the rete mirabile in animals was similar to that of the pituitary gland, which was "to separate the serous matter from the arterial Blood" ${ }^{69}$ Regarding the rete mirabile in man he referred to the view of "most anatomists" that it was lacking. Nevertheless, Drake went on to quote a long paragraph from Ridley's Anatomy of the brain on the appearance and function of the rete mirabile in animals to balance the pressure of the blood, and also confirmed that the wonderful net was not completely absent in man, but just much smaller than in animals. ${ }^{70}$ Rather than clarifying its status, Drake's account of the structure remained unclear and contradictory. A few chapters later, when he treated the nervous system, Drake developed a quite inventive solution for the problems surrounding the rete mirabile by simply declaring it negligible:

Surrounding this Gland [i. e. the pituitary gland] in the Sella Turica is a small Plexus of Vessels call'd RETE MIRABILE, which is either not existent in Men, or so very minute that its Existence is fairly doubted. In Brutes it is Conspicuous enough, and by Willis is said to consist of Arteries, Veins and Nerves; by Vieussens of Arteries only, and by others, of Arteries and small Veins. This is a Controversie not easie to be decided, and scarce worth the trouble. ${ }^{71}$

The controversies about the rete mirabile also puzzled Lorenz Heister. Heister was anatomy professor at the University of Helmstedt and author of the most successful anatomical textbook of the eighteenth century, the Compendium anatomicum (1717), which had more than thirty editions in five languages by $1777 .^{72}$ Heister even added to the confusion by confirming the existence of this inconspicuous and apparently inconsiderable object, stating that "its use is unknown". ${ }^{73}$ In later editions of the Compendium anatomicum he reaffirmed the existence of the rete mirabile in man and bristled at its denial by Frederik Ruysch. ${ }^{74}$ Although the famous Dutch anatomist "had erstwhile

${ }^{68}$ James Keill, The anatomy of the humane body abridge'd ..., London, Ralph Smith and William Davies, 1703 (1st ed. 1698), p. 144.

${ }^{69}$ James Drake, Anthropologia nova; or, a new system of anatomy: describing the animal oeconomy, and a short rationale of many distempers incident to human bodies ..., 2 vols, London, Samuel Smith and Benjamin Walford, 1707, vol. 2, p. 394.

${ }^{70}$ Ibid., pp. $394-6$.

${ }^{71}$ Ibid., p. 491.

${ }^{72}$ Heister's work, especially his surgical work and his correspondence with colleagues and patients, has recently received increased attention from medical historians such as Marion Ruisinger, Patientenwege: die Konsiliarkorrespondenz Lorenz Heisters (1683-1758) in der Trew-Sammlung Erlangen,
Stuttgart, Franz Steiner, 2008 (see bibliography for further references). However, Heister's anatomical investigations have so far received little attention.

${ }^{73}$ Lorenz Heister, A compendium of anatomy, London, Thomas Combes and James Lacy, 1721 (1st ed., Latin, 1717), p. 211.

${ }^{74}$ That Heister revised his account of the rete mirabile (although never denied its existence in human beings) in later editions of his Compendium anatomicum was unusual. In the anatomical handbooks of other authors, such as Vesling, Blankaart, Diemerbroeck and Keill, the passages on the wonderful net remained unchanged in the last editions published during their lifetimes (Vesling, Syntagma anatomicum, Padua, 1647; Diemerbroeck, Anatome corporis humani, Geneva, 1674; Blankaart, 


\section{The Representation of the Rete Mirabile in Early Modern Anatomy}

displayed this net with words and etchings, [he] now ranks it among the fairy tales". ${ }^{75}$ Heister referred to one of the illustrations in Ruysch's Epistola anatomica problematica duodecima (1699) (Figures $7 \mathrm{a}$ and $7 \mathrm{~b}$ ). ${ }^{76}$ The brain of the subject, according to the caption that of a ten-year-old boy, was represented from below, similar to the illustrations in Spiegel and Vesling. The rete mirabile (indexed on the left with the letter $\mathrm{T}$ ) featured on this illustration left and right of the optical nerve (indexed with letter D). Jan Wandelaar's delicate etching in Ruysch's Epistola anatomica appeared to be the last visual representation of the rete mirabile as part of human anatomy. The appearance and location of the wonderful net in this illustration was different from that in the images in Spiegel and Vesling. It was also less prominent and less noticeable, but shared the manner of a naturalistic representation with the structures of the brain.

Neither Heister's Compendium anatomicum, nor the other eighteenth-century anatomical handbooks featured illustrations of the rete mirabile. Nevertheless, the structure itself continued to appear in anatomical publications like An essay on comparative anatomy (1744) by the Edinburgh anatomist Alexander Monro primus. Monro insisted on a rete mirabile in human bodies, "notwithstanding several Anatomists have denied it's [sic] Existence". 77 Although he rejected the Galenic idea of the physiological function of the rete mirabile as "frivolous", Monro did not develop a different concept, but went on to discuss the difficulties which could occur during dissections of this subtle structure. ${ }^{78}$ His son Alexander Monro secundus, who also became professor of anatomy at the University of Edinburgh, followed the opinion of his father in his Observations on the structure and function of the nervous system (1783). In the first chapter, on the circulation of the blood in the head, he gave a brief description of the rete mirabile, explained that it regulated the blood flow into the brain, and stated that it could be discovered more easily in animals, adding an illustration representing the rete mirabile in a calf foetus. ${ }^{79}$ The etching showed the structure on its own, and the exact appearance and topographic relations of the rete mirabile remained unclear. ${ }^{80}$

By the end of the eighteenth century, however, the Monros were fairly isolated with their view. Midway through the eighteenth century Albrecht von Haller, who was at the time anatomy professor at the University of Göttingen, published his Iconum anatomicarum (1743-1756). Its illustrations, Haller claimed, represented as naturalistically as possible

Anatomia reformata, Leiden, 1695; Keill, Anatomy, London, 1718).

75 “. .. der ehemals dieses Nez mit Worten und Kupferstichen angezeiget hat, izo daselbe unter die mährlein zählet". Lorenz Heister, Compendium anatomicum ..., Nürnberg, Johann P Krauß, 1771 (1st ed., Latin, 1717), p. 315. Ruysch alluded in his later work to the "fables about the rete mirabile in the human head" ("fabulae de reti mirabile in capite humano"). He used them to exemplify the danger of using animal cadavers in anatomy and transferring the results to human bodies. See Frederik Ruysch, 'Adversariorum anatomico-medico-chirurgicorum. Decas secunda. In qua varia notatu digna recensentur', idem, Opera omnia anatomicophysico-chirurgica, Amsterdam, Jansson-Waesberg, 1720 , p. 45.

\footnotetext{
${ }^{76}$ Frederik Ruysch, 'Epistola anatomica problematica duodecima, authore Mich. Ernesto Ettmullero, M. D. \&c. ad virum clarissimum Fredericium Ruyschium, Med. Doc. Anatomiae \& Botanices Professorem, de cerberi corticali substantia, \&c.' (1st ed 1699), in idem, Opera omnia anatomicophysico-chirurgica, Amsterdam, Jansson-Waesberg, 1721, Tab. 13.

${ }^{77}$ Alexander Monro primus, An essay on comparative anatomy, London, J Nourse, 1775 (1st ed. 1744), p. 63.

${ }^{78}$ Ibid., pp. $63-5$.

${ }^{79}$ Alexander Monro secundus, Observations on the structure and functions of the nervous system, Edinburgh, William Creech; and London, Joseph Johnson, 1783, p. 2 and ibid., table I.

${ }^{80}$ Ibid., caption for table I.
} 


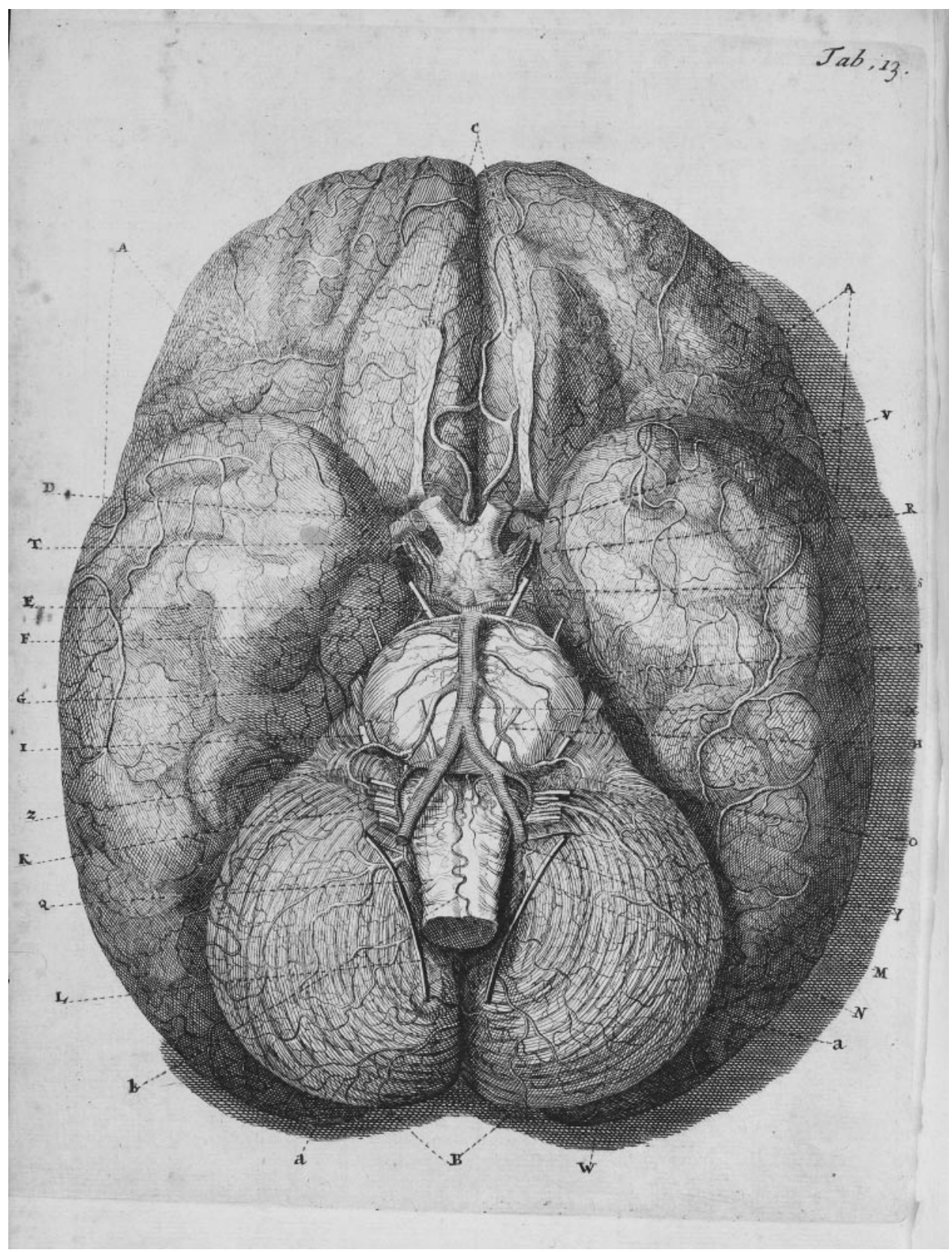

Figure 7a: F Ruysch, 'Epistola anatomica' (1721), Tab. 13, drawing by Jan Wandelaar. The letter $\mathrm{T}$ (on the left) indexes the rete mirabile. (Herzog August Bibliothek Wolfenbüttel. M: Ma 148.) 


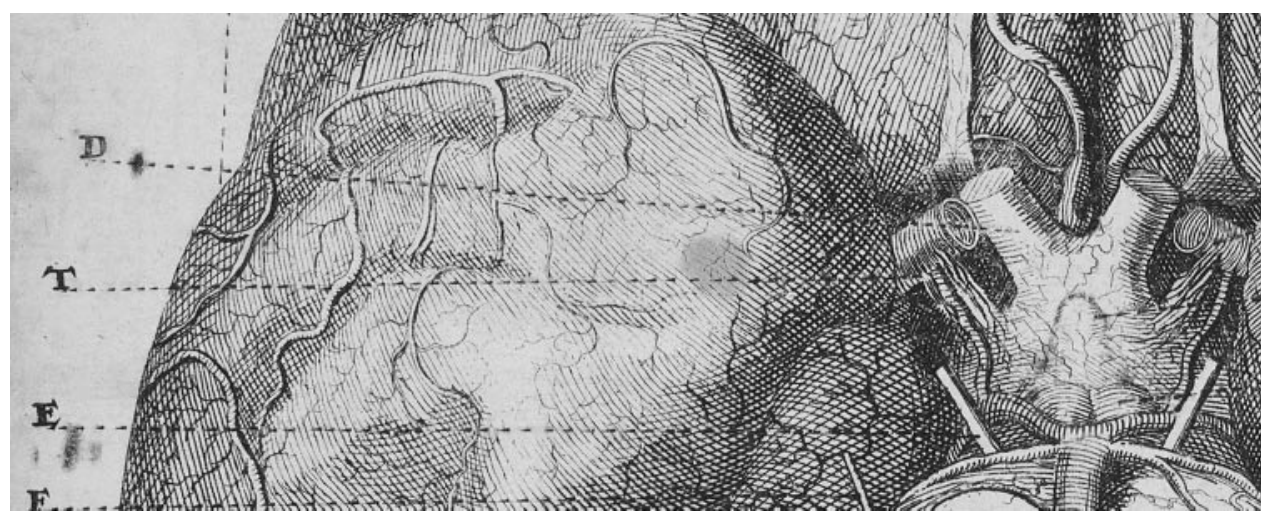

Figure $7 b$ : Detail of Figure 7a, showing the rete mirable to the left and right of the optic nerve. (Herzog August Bibliothek Wolfenbüttel. M: Ma 148.)

his actual observations during dissections. In the seventh part, on the arteries of the brain, the spinal cord and the eyes, Haller also discussed at great length the previous literature on the rete mirabile and came to the conclusion that no such structure existed in human bodies. He dismissed the idea that arteries at the base of the brain would form such a structure, and his only comment on the physiological function of the rete mirabile was that it was simply useless in man. ${ }^{81}$ The same opinion was held by the surgeon and anatomist John Bell, who wrote in his Anatomy of the human body (1797) that "in man there is not the smallest vestige of a rete mirabile". Bell justified his claim with the argument that because of his upright position, man would not need a structure to regulate the influx of blood to the head. ${ }^{82}$

A similar argument was used by the philosopher Johann Gottfried Herder in his Outlines of the philosophy of man (1784-1791). In these reflections on natural philosophy he developed the idea that what ultimately distinguished humans and animals was man's ability to walk upright. This ability was determined by man's anatomy and made him superior to animals. Herder was sure that unlike other animals neither human beings nor horses had a rete mirabile: "Because it's [sic] [i.e. the horse's] head stands erect, and the carotid artery rises in some measure like that of man, without having occasion for this contrivance to impede the course of the blood, as in brutes that have depending heads. Accordingly it is a nobler, fiery, courageous animal, of much warmth, and sleeping little., ${ }^{, 83}$ Herder's explanation of the absence of the rete mirabile in horses mixed ideas of the upright position as the distinction

\footnotetext{
${ }^{81}$ Albrecht von Haller, 'Iconum Anatomicarum. Quibus alique partes corporis humani delineatae traduntur. Fasciculus VII. Arteriae cerebri, Medullae spinalis, Oculi', 1754, in idem, Iconum anatomicarum partium corporis humani, Göttingen, Abraham Vandenhoeck, 1743-1756, p. 3.

${ }^{82} \mathrm{John}$ Bell, The anatomy of the human body, 2 vols, Edinburgh and London, Cadell and Davies, 1797, vol. 2, p. 337.
}

\footnotetext{
${ }^{83}$ Johann Gottfried Herder, Outlines of a philosophy of the history of man, London, J Johnson, 1800 (1st ed., German, 1784-1791), p. 80. On the Europe-wide contemporary reception and influence of Herder's Outlines, see Wolfgang Pross, 'Nachwort: "Natur" und "Geschichte" in Herders Ideen zur Philosophie der Geschichte', in Johann Gottfried Herder, Werke, Band 3.1: Ideen zur Geschichte der Menschheit, Munich, Hanser, 2002, pp. 883-1041, on pp. 1021-41.
} 


\section{Sebastian Pranghofer}

between humble animal and nobler man with physiological explanations of the rete mirabile which had developed during the seventeenth century.

Such physiological theories had paved the way for a transformation which turned the rete mirabile into an exclusive property of certain animals, but was absent from humans. ${ }^{84}$ By the end of the eighteenth century the wonderful net had finally vanished from human anatomy. This was reflected in new handbooks like Vom Baue des menschlichen Körpers (1791-1796), published in six parts by the German anatomist Samuel Thomas Soemmering. Although he opposed a strict distinction of anatomy and physiology, ${ }^{85}$ Soemmering nevertheless introduced a rigid taxonomy based on dissection, empirical observation and meticulous description. This meant that the parts and structures of the human body were classified and summarized strictly according to their appearance and correlation. Consequently, Soemmering treated angiology and the anatomy of the brain and nerves in two separate volumes. ${ }^{86}$ With no link between the anatomy of the vascular system and the anatomy of the brain and nerves, no room was left for the rete mirabile. Soemmering regarded the vascular and the nervous systems as separate with distinct structural, physical and physiological features. While the vascular system was preoccupied with nourishing the body and balancing the bodily fluids, the nervous system transmitted sensory information. Soemmering admitted that the way the nerves worked was unknown. ${ }^{87}$ However, he thought of the nerves as fibres and rejected the idea that they were vessels transporting "nervous juice" (Nervensaft) ${ }^{88}$ Therefore an organ, such as the rete mirabile, which would transfer a substance from one system to another, did not make sense any more.

The rete mirabile in man only resurfaced in clinical medicine in the $1950 \mathrm{~s}$ and led to some controversy over its terminology. In their paper 'The myth of the rete mirabile in man' (1972), the American radiologists C G de Gutiérrez-Mahoney and M M Schechter strongly argued against using the term rete mirabile to identify collateral vessels at the base of the brain. They referred to six medical papers from the 1950s and 1960s which used the term in a clinical context. ${ }^{89}$ Based on a historical overview and a review of twentieth-century literature on the rete mirabile in animals, Gutiérrez-Mahoney and Schechter argued that "the use of the term rete mirabile ... should be discontinued if only for the sake of clarity". ${ }^{90}$ Modern debates still carried rudiments of the seventeenthand eighteenth-century debates, as when the rete mirabile was described in modern medical literature as a compensatory structure of collateral vessels and linked to cerebral

\footnotetext{
${ }^{84}$ The history of the rete mirabile in comparative anatomy is discussed in

Forrester, op. cit., note 2 above. He follows the research on the structure and function of the rete mirabile until the 1960s. By this time a

new concept had been established, namely that the function of the rete mirabile in animals was not to regulate the blood flow into the brain, but to regulate the temperature of the blood in the brain. Ibid., pp. 210-16.

${ }^{85}$ Samuel Thomas Soemmering, Vom Baue des menschlichen Körpers, part 1, Knochenlehre, Frankfurt/Main, Varrentrapp und Wenner, 1791, pp. XXIV-XXV.
}

\footnotetext{
${ }^{86}$ Soemmering described the vascular system in Samuel Thomas Soemmering, Vom Baue des menschlichen Körpers, part 3, Gefäßlehre, Frankfurt/Main, Varrentrapp und Werner, 1792. The anatomy of the brain, however, was treated in idem, Vom Baue des menschlichen Körpers, part 5, Hirn- und Nervenlehre, Frankfurt/Main, Varrentrapp und Werner, 1791.

${ }^{87}$ Ibid., p. 159.

${ }^{88}$ Ibid., pp. 106-12, 163-8.

${ }^{89} \mathrm{C}$ G de Gutiérrez-Mahoney, M M Schechter, 'The myth of the rete mirabile in man', Neuroradiology, 1972, 4: 141-58, pp. 153-5.

${ }^{90}$ Ibid, p. 157.
} 


\section{The Representation of the Rete Mirabile in Early Modern Anatomy}

haemorrhage. ${ }^{91}$ This assessment resonated with Willis's assumption that in man the rete mirabile could be found only in fools, or Herder's belief that the lack of a rete mirabile in man indicated his more perfect constitution.

\section{Conclusions}

The astonishing longevity of the rete mirabile in human anatomy reflects fundamental methodological and epistemological problems of early modern anatomy. Until the second half of the eighteenth century the rete mirabile could be understood as an ambiguous object between anatomical tradition, empirical research and physiological interpretation, which were unified in the "old anatomy" as a "discipline for research on life". 92 However, since the middle of the seventeenth century, iatromechanist concepts replaced the teleological Galenic ideas in academic medicine and a more rigid empiricism became the dominant method in anatomical research. ${ }^{93}$ Steno's programmatic lecture on the dissection of the brain paradigmatically represented this approach. Although he was aware of the possibility of misperception and manipulation, he gave visual and tactile observations prevalence over theory. ${ }^{94}$ This method implied that doubts about the existence of a certain structure like the rete mirabile had far-reaching consequences for its physiology. If the form, structure and appearance of a certain object were doubtful, its physiological function had to be questioned as well and attributed to some other structure. In the case of the wonderful net, this explains why the problems with identifying the structural anatomy of the rete mirabile resulted in a reinterpretation of its physiological function, but did not immediately make it an obsolete object.

Such doubts led to increased uncertainty about the identity of the rete mirabile in human bodies, which was reflected in the avoidance strategies of the authors of anatomical handbooks and textbooks from the second half of the seventeenth and first half of the eighteenth century. Instead of taking a firm stance, most of them vacillated and either discussed at great length which authors had denied the rete mirabile and which accepted it (Diemerbroeck), or simply stated that although smaller than in animals it also existed in man, but did not give any account of its function (Verheyen, Heister). Others gave iatromechanist explanations of the rete mirabile as an organ which regulated the speed of the blood flow, but did not specify whether they were referring to human or to animal bodies (Keill). Yet another strategy was to simply end the discussion by declaring that the whole controversy about the rete mirabile was negligible (Drake).

The uncertainty about the rete mirabile was also reflected in, and aggravated by, its visual representations. In the beginning of the sixteenth century and in Vesalius's

\footnotetext{
${ }^{91}$ Ibid., and Mikami, Takabashi and Houkin, op. cit., note 1 above.

${ }^{92}$ Cunningham, op. cit., note 64 above, p. 55.

${ }^{93}$ Harold J Cook, 'The new philosophy and medicine in seventeenth-century England', in Lindberg and Westmann (eds), op. cit., note 66 above, pp. 397-436; Roger French and Andrew Wear (eds), The medical revolution of the seventeenth century, Cambridge University Press, 1989; Karl E Rothschuh, Konzepte der Medizin in Vergangenheit und
}

Gegenwart, Stuttgart, Hippokrates Verlag, 1978, pp. 164-70, on empiricism in seventeenth- and eighteenth-century medicine, and pp. 228-40, on iatromechanism in seventeenth-century medicine. On anatomy and the Cartesian "new philosophy", see Roger French, Dissection and vivisection in the European Renaissance, Aldershot, Ashgate, 1999, pp. 253-73.

${ }^{94}$ Steno, op. cit., note 35 , pp. $144-5$. 


\section{Sebastian Pranghofer}

Tabulae anatomicae the rete mirabile was still part of a visual paradigm, where it could not only be represented in situ but also with a function within a physiological system (Figure 2). However, the denial of its existence in human bodies in Vesalius's Fabrica also visually separated the rete mirabile from the human body. When the rete mirabile was represented in relation to the human brain during the seventeenth and eighteenth centuries, it appeared in different shapes and places. These illustrations failed to become self-evident and standardize the gaze and its object, an ambition seen by Lorraine Daston and Peter Galison in anatomical atlases from the sixteenth to the eighteenth century. ${ }^{95}$ Because illustrations of the rete mirabile did not develop a consistent iconography, the seventeenth- and eighteenth-century visual representations of this structure carried the uncertainty about its identity forward and did not lead to self-evident and "very normal images". ${ }^{96}$ Rather than establishing the rete mirabile as a matter of fact in the anatomical discourse, the iconographic inconsistency and the ambiguous narratives allowed the rete mirabile to survive in human anatomy until there occurred a clear disciplinary division into descriptive anatomy and experimental physiology around the turn of the eighteenth to nineteenth century. ${ }^{97}$

The further development of a rigorously empirical method in anatomy led to the gradual separation of anatomy from physiology from the end of the eighteenth century. The "old anatomy" which had integrated topographic description with the bodily functions was replaced by a systematic approach which focused on the clear identification and meticulous description of the appearance of the human body. Although Soemmering, for example, did not yet give up the idea of a unity of anatomy and physiology in his Vom Baue des menschlichen Körpers, his systematic approach led him to discuss the structure, form and function of the brain separately from both the nerves and the vascular system. Within such a system, a structure such as the rete mirabile, which was formed by blood vessels and provided a substance to the nervous system, which was formed by fibers, did not fit. Further specialization and the successive institutionalization of the disciplines of anatomy, physiology, pathological anatomy and zootomy from the beginning of the nineteenth century finally handed the wonderful net over to the domain of animal anatomy. However, the notion of a deficient nature of the early modern wonderful net survives in the modern rete mirabile as a pathological structure linked to brain haemorrhages, as described in the paper cited in the introduction.

\footnotetext{
${ }^{95}$ Lorraine Daston, Peter Galison, 'The image of objectivity', Representations, 1992, 40: 81-128, pp. 84-95.

${ }^{96}$ David Gugerli and Barbara Orland, 'Einleitung', in idem (eds), Ganz normale Bilder. Historische Beiträge zur visuellen Herstellung von Selbstverständlichkeit, Zürich, Chronos, 2002, pp. 9-16, on p. 11. Gugerli and Orland defined "very normal images" in modern sciences as images, which had become self-evident and whose meaning was obvious and doubtless within a scientific discourse.

${ }^{97}$ Andrew Cunningham, 'The pen and the sword: recovering the disciplinary identity of physiology and anatomy before 1800: I, old physiology - the pen', Stud. Hist. Phil. Biol. Biomed. Sci., 2002, 33C:
}

631-65, and idem, op. cit., note 64 above. In Germanspeaking countries, for example, only from the late eighteenth century were journals published which reflected the development of a disciplinary division, e.g., the Magazin für die pathologische Anatomie und Physiologie, Altona, 1796, or the more successful Archiv für die Physiologie, Halle/Saale, 1796-1815. For the institutional establishment of the new disciplines at universities in the German territories, Austria and Switzerland since the early nineteenth century, see Hans-Heinz Eulner, Die Entwicklung der medizinischen Spezialfächer an den Universitäten des deutschen Sprachgebietes, Stuttgart, Ferdinand Enke, 1970, pp. 31-65. 